\title{
Rethinking Soviet Democracy
}

\section{Popular Participation in Family Law Reform after Stalin}

The purpose of this article is to reveal which elements of the ideas of Soviet democracy legitimized the direct participation of the people, how these ideas shaped the legislative process, how people participated in the law-making process of the new family law of the union, and finally how the Communist Party and draft makers, including state officials and specialists, worked with popular participation. It took about 20 years to adopt the law, and the reason why it took so long was deeply rooted in the ideas of Soviet democracy. The Soviet regime was democratic in its own sense of the word and this article gives it a more democratic face than what is usually imagined, especially among Western people. However, the regime's unique democratic character seemed to make it rather difficult to function adequately.

KEYWORDS: Soviet Union, democracy, socialism, policy making, family law

Kazuko Кашамото is Visiting Associate Professor at Doshisha University (k_kawamoto@nifty.com). Her interest lies in Russian and Soviet history. The author wishes to thank an anonymous commentator for his or her helpful suggestions. 
THE WORDS "Soviet democracy" may sound odd to many, especially in the younger generation, while to others in the older generation they may bring back memories of the "good old" Cold War years, when they supported liberal democracy against Soviet socialist democracy, or vice versa. Many Cold War contemporaries thought that there was such a thing as Soviet democratic theory, despite not believing the Soviet government's claim of the superiority of Soviet democracy over liberal democracy (Held 2006, ch. 4; CRICK 2005, ch. 3; MACPHERSON 1972, 12-22; TALMON 1952). Nevertheless, the idea of Soviet democracy is widely understood as false today. There is a widespread belief that the Soviet regime was simply oppressive and totalitarian, and not democratic at all. Critics have often blamed the Soviet regime for lacking liberty, which undermined the meaning of political participation (DAHL 1971, 5; FRIEDRICH and BRZEZINSKI 1965, 161-71).

However, the Soviet government did encourage the working people to speak out. As numerous studies have shown, Soviet citizens responded by writing letters and visiting government offices to address the authorities, even if there were limits to the realization of their demands and the effectiveness of their entreaties (MATsudo 2008; Bittner 2008; ZubKova 2000; Fitzpatrick 1996; Friedgut 1979; Oliver 1969). These studies showed that people demanded to be heard and the authorities responded, however insufficiently, because the ideas of democracy obligated them to do so. My purpose in this article is to examine which elements of Soviet democracy legitimized political participation through the process of writing letters to the authorities, and how this process shaped the political course, by concretely examining the process through which one particular law was created. The case I examine is the legislative process for the Principles of Legislation on Marriage and the Family of the USSR and the Union Republics (hereafter referred to as the Principles). In the next section, I briefly review the theory of Soviet democracy and the changes in it over time and, after pointing out several features of Soviet family legislation, discuss how citizens' demands reached the authorities and how the specialists and officials who drafted the legislation reacted to those citizen demands. Since my focus here is on direct participation, I do not discuss indirect participation such as elections.

\section{What was Soviet Democracy in Theory?}

The original theory of Soviet democracy, described in State and Revolution by LENIN (1977), emphasized self-government of the workers who, as the proletariat, shared fundamentally common interests (PRIESTLAND 2002; 
КАШАмото 2002). This was called the dictatorship of the proletariat. In this theory there was no fixed division of labor in politics, as such divisions might give rise to separate interests that would destroy the political unity of the workers and create, as a consequence, an exploiter and the exploited. Soviet democracy was for workers and exploited people only. Another theoretical expectation was that a communist society would arise someday in the future, after socialism had become established and people were accustomed to governing themselves, and there would be no need to maintain state organs for enforcing policies. In this way, the state would wither away, and so would politics.

In line with the idea of the dictatorship of the proletariat, the Soviet regime excluded a certain category of people, known as lishentsy, which included capitalists, former officers of the White Army, and clergy, by depriving them of the right to vote (Alexopoulos 2003). Later, the Stalin constitution of 1936 democratized the franchise and made it possible for all citizens to vote on the grounds that the socialist state had been basically built. This meant that exploiting classes no longer existed, and the gap between the remaining classes, namely workers, peasants, and intelligentsia, had decreased (STALIN 1997a, 121-24). Thereafter, not only the proletariat but all citizens with common interests were to participate directly in the governing process. However, although theoretically the state should be withering away on the road to communism, Stalin insisted on strengthening the state because the class struggle would intensify due to stubborn resistance from the former rulers and exploiters (STALIN 1951, 210-11).

After Khrushchev came to power, he placed new emphasis on the withering away of the state and attempted further democratization, inserting an intermediate stage between the socialist state and the communist society in the new Party Program of 1961. This was the all-people's state, which encouraged all citizens to participate more widely in government (Titov 2009; BURLatskil 1962; LePeshKin 1962). According to this new doctrine, state functions were to be gradually transferred to the people to build a communist society. It was not accidental that "all-people's discussions" (vsenarodnoe obsuzhdenie) were often held during the Khrushchev government at times when important state and party policies were to be adopted (Коток 1964, 121-25). The family law discussed in this essay was not exceptional, although the discussion actually took place under the Brezhnev government. The government also encouraged people to write letters as a way of participating politically, and the Central Committee of the Party issued the decree "On the serious shortcomings in the examinations of letters, complaints, and declarations of the workers" in 1958 to 
ensure the letters would be handled properly (Kommunisticheskaia Partiia 1986, 251-55).

In Soviet democracy the sharing of common interests by all people was crucial in order to avoid political and social cleavage, as mentioned earlier. This "unanimity of interests" in turn affected the public/private distinction in Soviet society as a whole. As a plurality of interests was seen as a danger to Soviet socialist democracy, there was no acceptable defense for holding diverse values, beliefs, and world views (HASEBE 2006, 55). In other words, one could not expect the Soviet authorities to respect an individual who privately held values that differed from the accepted ones. There was no reason to allow subjects to escape political scrutiny, which was needed to maintain identical interests. Therefore, the theory of Soviet democracy did not have a public/private distinction. Although this does not mean that no private sphere existed in Soviet society, the theory of Soviet democracy did not have any norms that prevented any one person from intervening in the lives of others. As far as the de facto private sphere was not recognized, such actions could not be viewed as interventions.

However, what constituted a unanimity of interests was modified from time to time. For instance, Stalin's idea of the intensifying class struggle may have contributed to narrowing the scope of interests accepted as legitimate. According to Stalin, under the intensified class struggle, enemies penetrated the state and party organs by masking their true faces so that Party members had to be strict in their vigilance in all situations in order to discover them (STALIN 1997b, 151-52). Thus, especially when people were eager to unmask enemies, the smallest deviation could be sufficient proof of enemy activity. ${ }^{1}$ Nevertheless, the range of acceptable workers' interests increased after Stalin, although to a limited extent. Even before Khrushchev criticized Stalin in his secret speech on the cult of personality, some philosophers had already begun to argue that diverse interests in fact existed in Soviet society, although the interests were not antagonistic to each other in nature so that they would be reconciled (STEPANIAN 1955; GAK 1955). Expanding the range of acceptable interests helped to activate discussion because the masses would be able to worry less about whether their demands and proposals remained within the ideological limits. However, the regime not only continued "to employ punitive responses against those who were perceived as being 'genuinely anti-Soviet" but also developed more sophisticated ways of preventing dissenting activities (HORNSBY 2011, 69).

1. In this way, the theory of intensifying class struggle justified "the Great Terror campaign on the late 1930s" (Titov 2009, 16). 
Regarding the unanimity of interests, the Communist Party held a unique position in Soviet democracy. As the vanguard, communists had to guide the people to socialism and then communism. Thus, the communists had to decide what constituted the workers' interests. In this regard, the role of the Communist Party and its leadership was crucial in determining the content of every policy. The Party was entitled to intervene in the policy-making process at every stage to secure the interests of the workers, according to their own definition. Educating people was also an important task. People might not realize their true socialist interests as the communists expected them to, and therefore the communists had to expend much effort in education and propaganda to make people understand their proper place in society, whether or not they wanted to.

This brief review of the theory of Soviet democracy gives rise to many questions. First, it seems impossible, or at least unrealistic, that everyone could participate in government directly and successfully to the extent that the state would wither away. What did the Soviet government do to give a sense of reality to this fiction?

Second, a unanimity of interests also seems unrealistic in that it would be unnatural for every person in society to share the same interests. Although limits on the plurality of values, such as a ban on marriage between close relatives and the criminalization of pedophilia, exist even in liberal societies, the permissible range of Soviet values and interests was much narrower because it was based on specific ideological grounds, even after the unanimity of interests was relaxed. On the other hand, it was not easy to choose which of the various proposals people sent to the authorities were appropriate. The socialist or communist ideology did not always provide only one right answer to any given policy question, for the ideology itself consisted of various elements.

Finally, the role of the Communist Party should be scrutinized. Although Soviet democracy expected the Party to engage in the policy-making process to make sure that the workers' interests were satisfied, Party members were not elected by popular vote, and no one could check on them other than they themselves. Moreover, their legitimacy was based on ideological doctrine only. Their acts could therefore be considered undemocratic and illegitimate, especially when compared with Western democracy based on competitive election. The Party had to earn the trust of the masses through either ideological appeal, improvement of living standards, or both. Furthermore, despite the difficulty of determining ideologically appropriate policies, the Party had to decide everything in the end; otherwise, the political process would come to a standstill. 


\section{Features of Soviet Family Law and its Reform}

Before we discuss popular participation in the reform of the family law, we should note several points. Since the issues of family law were not particularly political, discussion of law reform was easy and people could say what they thought with less reservation than, say, when they had to talk about the new Party Program. Thus, it may not be appropriate to generalize the frankness that was seen in the discussion on family law.

Nevertheless, Soviet family law was not as apolitical as it seems at first glance. After implicitly abandoning the Marxist notion of the "withering away of the family," the Soviet government adopted a new policy of "strengthening of the family" in the mid-1930s (AтTwOod 2010, ch. 6; GoLDMAN 1993, 304-10). Under the new policy, parental responsibility for children's misconduct increased (GEIGER 1968, 92). The government launched a "campaign against sexual promiscuity, quick and easy marriage, bigamy, adultery, and the exploitative approach toward women" (GEIGER 1968, 94). Under the revised family policy, the scope of legal actions related to marriage and family that could be taken freely narrowed, raising the possibility of the state's intervention. SverdLov $(1941,58)$, who later helped draft the law, stated that "freedom itself is attained here [in the family law area] as a result of regular urging from government" and that "the socialist government does not adopt a pose as a bystander and register of these relations [such as marriage and family], and reserves quite a considerable area of direct and active intervention in these relations."

The Soviet family law was amended fundamentally in 1936 according to this new policy line (Sz SssR 1936, 34, 309) and more drastically in 1944 because of the huge population loss in the Second World War (Vvs SssR 1944, 37; NAKACHI 2006). ${ }^{2}$ First, the extremely easy divorce procedure under the 1926 Russian family law (SU RSFSR 1926, 82, 611), ${ }^{3}$ which allowed either spouse to instantly dissolve the marriage, was made more difficult in the 1936 amendment and replaced with a highly complicated and timeconsuming procedure in 1944. Second, the amount of child support was determined according to the number of children under the 1936 law. Third, although unregistered de facto marriage was valid under the 1926 Russian

2. The Soviet Union lost 20 to 27 million soldiers and civilians during the war (Poliakov and ZHIROMSKaIA 2001, 130). The group that suffered most was young males. The ratio of men to women of reproductive age was 2 to 3 at the national level in 1946 (ANDREEv, DARSKII, and KHAR'KOVA 1993, 126-27).

3. Other union republics patterned family laws after Russian law. 
family law under certain conditions, the 1944 amendment prescribed that only registered marriage should be recognized as legally valid. The most serious change brought by the 1944 amendment was the abolishment of procedures for establishing paternity, which had been enacted right after the October Revolution. Now, the only way for parents to legitimize children born out of wedlock was to marry. Children born out of wedlock were deprived of the right to their father's family name, and the biological father's name was not on the children's birth certificate. Mothers of such children, called lone mothers (odinokie materi), could not claim financial support from the biological fathers. Instead, the mothers were provided with an insignificant child benefit by the government. This change meant that fathers were no longer obliged to pay child support for children they fathered outside of marriage and this, combined with the complicated divorce procedure, led to many children being born out of wedlock. ${ }^{4}$

Third, it took a long time to pass the Principles. Drafts of the Principles began to be prepared in 1948 under Stalin's government. ${ }^{5}$ However, only after Stalin's death did the state organs consider revising existing family law. Although important issues were clarified and discussed fully by the early 1960s (КАWAмOто 1998; JUVILER 1967), the Principles were adopted only in $1968 .{ }^{6}$ During these years, there were three forms of direct participation in this process: letter writing, interviews, and discussion in localities and all-people's discussions (vsenarodnoe obsuzhdenie), which I will examine in the following sections.

Fourth, the limits to criticism on this matter are unclear; I have not found any archival material showing that anyone was oppressed because they demanded changes in the family law. However, a hint about these limits was seen in a discussion held by specialists and officials on April 17,

4. Illegitimacy was widespread, especially in the cities, right after the Second World War. In 1945, more than a quarter of urban newborn children were illegitimate. The number of children born out of wedlock from 1945 to 1963 totaled more than 13.5 million, about 15 percent of all newborns in the USSR (GARF: 7523/101/2533/11, 20, 21, 30).

5. The Council of Ministers of the UssR resolved to prepare the Principles on December 17, 1948 (GARF: 5446/1/354/215-16).

6. For details of the entire process, including a discussion of the meaning of the family in the Soviet regime, see КАWAмото (2012) and CARLBÄCK (2009). Although Carlbäck correctly showed what had been discussed regarding establishing paternity, she made crucial mistakes when she categorized those who participated in drafting the legislation. For example, she listed Orlova as a deputy, but Orlova was a legal expert from the Institute of State and Law of the Academy of Sciences of the UssR and a member of a subcommittee founded by deputies. 
1956 (GARF: 9514/1/548/106-32). Some of those present argued that it was wrong to have abolished the procedure for establishing paternity in 1944 to begin with. An official rebuked them for being arrogant in thinking that the Party and the government had gone the wrong way and advised them to change their tone if they wanted the leaders to listen to them. Denying an existing policy entirely could have been understood as anti-Soviet, so it was safer to demand revision without any display of hostility. The critics apparently took the advice, and it does not seem that anyone was excluded from the drafting of the Principles due to their criticism.

\section{People Write to the Authorities}

Soviet citizens wrote letters to the authorities when they wished to make petitions, proposals, and demands. People knew that Soviet democracy legitimized the act of sending letters; therefore, those who wished to change the existing family law naturally wrote letters to the authorities. The letter writers can be divided into two categories. Some people sent letters when they wanted to settle personal problems related to marriage and family. ${ }^{7}$ They are minority voices in the archival files. Other letter writers proposed changing specific parts of the family law. Although their letters were also often based on individual grievances, these writers did not want to make the problems personal but instead tried to generalize them, showing that they were caused by the unfair institutions under which many people suffered. ${ }^{8}$ Actually, citizens often wrote letters collectively, sharing anger and sorrow and discussing what should be done. ${ }^{9}$

It was generally difficult for people to know exactly to which organizations they should submit their opinions. However, Soviet citizens who demanded new family laws did not have to be accurate in selecting addresses, because the letters were forwarded by the first recipients to the

7. One expecting lone mother in Stavropol City petitioned for her future baby to have his or her father's name on the birth certificate as an exception (GARF: 9514/1/71/55).

8. A lone mother in Kirgizia Republic complained at the beginning of a letter that " $[t]$ he existing law on payment of alimony only takes into account interests of men and deprives women and children of any rights" and only then she wrote, "[a]s an example, I can bring myself” (GARF: 9514/1/71/117).

9. There were many such collective letters, such as from a parents' committee of a school in Lvov oblast (GARF: 9514/1/140/85-86), a group of "young and women-mothers" in Voronezh oblast (GARF: 9514/1/173/62), "a group of women and mothers of Odessa" (GARF: 9514/1/140/96-100), and "nineteen old Bolsheviks" (GARF: 7523/45/439/153-55). This collective letter writing could be a reflection of important changes in society, for most letters to the 
responsible organizations. Later, the Soviet government enacted a law that required state and other organizations to forward letters to the appropriate authorities if they received letters that contained problems they were not competent to deal with (Vvs SssR 1968, 17, 144). Thus, citizens sent letters to various addresses, such as the Central Committee of the Communist Party, the Council of Ministers of the UssR, the Presidium of the Supreme Soviet of the UssR, editors of newspapers such as Pravda and Izvestiia, law journals, and women's magazines, and to important political figures such as Khrushchev as the first secretary of the Central Committee of the Party, E. A. Furtseva as the only woman in the Politburo, and deputies of the Supreme Soviet of the UsSR. Letters were redirected to the two main institutions that drafted numerous versions of the Principles: the Juridical Commission of the Council of Ministers of the UssR and the Commissions of Legislative Proposals of the Chambers of the Supreme Soviet of the UssR.

The Juridical Commission was established in 1956 to take over duties of the Ministry of Justice of the USSR, which was dissolved in the same year (Vvs SssR 1956, 12, 250). One of the first assignments for this commission was to prepare drafts of the Principles (GARF: 9514/1/3/1-4). Upon receiving letters, the Juridical Commission wrote back to the senders to show that their opinions were read and considered. Usually, the answers were simple, as in the following:

Regarding your letter, sent to the Central Committee of the KPSs, I report that your proposals on the payment of alimony for raising children who have been born from persons in an unregistered marriage will be considered for the elaboration of the Principles of legislation of the USSR on marriage and family.

(GARF: 9514/1/71/60)

However, other types of responses were also sent. The Juridical Commission sometimes explained the existing family law ${ }^{10}$ and even gave legal advice to letter writers. ${ }^{11}$ In one particular case, the commission took the

authorities in the 1930s were "written by single authors, not by groups, collectives or associations" (FitzPatrick 1996, 80). For more on this point, see KaWAmoto (2012, 231-33).

10. When a lone mother wished to fill in the blank for the father's name on the birth certificate of her child, after having received a letter in which the father admitted his paternity, the Juridical Commission pointed out that it was impossible under the existing law to write the father's name on the birth certificate of a child born out of wedlock unless the parents were married (GARF: 9514/1/ 71/100, 102-8).

11. The Juridical Commission provided instructions to a man on how to divorce when the present address of his spouse was unknown (GARF: 9514/1/140/69, 71-710b). 
trouble to ask the Moscow Bar Association to help a specific letter writer (GARF: 9514/1/100/94). The commission also occasionally rebuked writers or expressly noted that their opinions were in the minority. ${ }^{12}$

The Juridical Commission presented the final draft of the Principles in October 1959 to the Council of Ministers. However, the legislative process reached a deadlock. One reason for this failure, according to a later comment by an official working in the Council of Ministers, was the conditions for establishing paternity in the draft, as this was related to demographic concerns (GARF: 7523/101/2585/281). Policy makers feared that the new law might decrease the birth rate, since the 1944 edict indirectly encouraged men to have extramarital relationships by freeing them from paying child support for children born out of wedlock. Nevertheless, it is unlikely that the Council of Ministers, and probably the Party, completely rejected the drafts since another organ, the Commissions of Legislative Proposals of the Chambers of the Supreme Soviet of the USSR, took over the project in November 1961 (GARF: 7523/45/382/29) and began working based on the drafts of the Juridical Commission, including the conditions for establishing paternity.

The Commissions of Legislative Proposals was a standing commission of the Supreme Soviet of the Ussr. One of its duties was preparing and examining bills (Zasedaniia Verkhovnogo Soveta SSSR 1947, 395-400). However, since the members of these commissions often lacked legal knowledge and experience, they instituted a subcommittee consisting of legal experts, ministry and other state organ officials, and representatives of other organizations. Unlike the Juridical Commission, the Commissions of Legislative Proposals seemingly did not write back to those who sent proposals for drafts (GARF: $7523 / 45 / 303 / 81-83$ ). Instead, the staff working for the commissions classified the proposals and extracted parts from them to provide the subcommittee with material for the drafts. ${ }^{13}$ While specialists and officials were discussing and determining the conditions to be included in the drafts, in accordance with their own opinions based on study and ideological belief, they also carefully examined letters and decided whether any parts of them should be included in consideration (GARF: 7523/101/2586/55-59, 192-96). Moreover, proposals sometimes pushed subcommittee members to seek drastic changes, especially when numerous citizens sent the same demands, such as with regard to establishing paternity. S. V. Baksheev, a member of the subcommittee

12. In response to a letter written by two women, the Juridical Commission wrote that it would not agree with a ban on divorce of the elderly (GARF: 9514/1/100/ 69, 71-72).

13. There were thirteen sets of materials made (GARF: 7523/45/439/1-279). 
and an official of the Juridical Commission, said that, "in the overwhelming majority of letters, 90 percent of them, they wrote angrily" about the existing standards for children born out of wedlock, and the Juridical Commission received letters "with almost anti-Soviet contents" (GARF: 7523/101/2584/101-4). Those who opposed broad conditions for establishing paternity rarely mentioned demographic concerns in the subcommittee, but instead insisted on preserving the existing norm to prevent women from carelessly entering into sexual affairs and possibly breaking up existing families (GARF: 7523/101/2586/67-68).

\section{Collecting Opinions in the Union Republics and Universities}

The draft makers were not only passive recipients of letters but also traveled throughout the Soviet Union to listen to the people. When the work in the Commissions of Legislative Proposals was reaching its end, members of the subcommittee and officials working for them visited several union republics from April to June 1962 to research the practice of family law and collect opinions on important standards in the draft of the Principles, such as the establishment of the paternity of children born out of wedlock, divorce procedures, and monetary support for children after divorce. ${ }^{14}$

After these research trips, the commission finished the draft and presented it to the Central Committee of the Party in July (GARF: $7523 \mathrm{sch} / 108 \mathrm{ss} / 393 / 10$ ). However, the legislative process stalled again, apparently because of the range of conditions for establishing paternity. Although the possibility of establishing paternity was reduced in the next draft, ${ }^{15}$ it was increased again to some extent in most of the subsequent versions of the draft. ${ }^{16}$ Moreover, members of the subcommittee and officials visited additional republics in February to March and July to August

14. They went to the republics of Lithuania, Estonia, Moldavia, Armenia, Kirgiz, and Ukraine as well as the Dagestan autonomous republic in Russia (GARF: 7523/45/360/46, 75).

15. In the draft presented to the Central Committee, the provision for establishing the paternity of children born outside wedlock was as follows: "On the establishment of paternity, the court starts with the fact of cohabitation of the plaintiff and the defendant, or conducting common household by them, or the joint upbringing of the child or the financial support to the child, or other circumstances confirming the fact that the child was born from the defendant" (GARF: 9514/1/549/27-43). The next draft lacked the last part, "or other circumstances ..." (GARF: 9514/1/551/204-34).

16. The typical wording was as follows: "[O]r existence of the stable character of close relationships which developed between parents" (GARF: 7523/101/2593/103-21). 
1963 while preparing the drafts. ${ }^{17}$ As a result, they conducted research and held hearings in all of the union republics at least once.

During the visits to the republics, several meetings were held that gathered local scholars, judges, procurators, and officials of state organs. On some occasions, meetings were held in other places to hear the voices of ordinary people who were likely to be interested in family law. For example, in Latvia, meetings were held at a textile plant and a flax plant, where most of the workers were women who supposedly suffered from the existing law on children born out of wedlock. The draft was also discussed at the Administration of Border Troops and at a meeting of officers of the Ashkhabad garrison "at the request of local comrades" in Turkmen (GARF: 7523/45/443/66-68). Military authorities, as well as officers and soldiers, were probably interested in this matter because many young men had relationships with local girls and because many paid support for their children after divorcing. ${ }^{18}$

In addition to these trips, the Commissions of Legislative Proposals sent a draft in February 1963 to thirty-three institutes and universities in all union republics seeking comments (GARF: 7523/45/371/2-3; GARF: $7523 / 45 / 443 / 10 b)$. Some universities held conferences on the draft of the new Principles (GARF: 7523/45/443/66-68). Isamu Fujita, a jurist of the University of Tokyo who was living in Moscow that year, heard a report on the draft at a conference at Moscow State University (BELIAKova 1970, 158).

Traveling to the republics and sending the draft to universities in this way provided more precise information about the drafts of the Principles to local citizens, especially those who were concerned about the family law, such as experts and other interested persons, and this encouraged them to send their opinions to the central authorities. These activities of giving information and listening to the people surely served the purpose of the Soviet method of direct democracy, as A. I. Pergament, a family law expert and a core member of the subcommittee, proudly stated after her visit to Moldavia:

First of all, I would like to note that such an attempt of trips to the republic, when still talking on only preparation of the draft, has been extremely well approved in the regions: comrades considered it as a manifestation of the widest democratic character in preparation of our laws, especially such law

17. Travels were to the republics of Belarus, Kazakh, Azerbaijan, Georgia, Latvia, Turkmen, Uzbek, Tajik, and some Russian cities and regions (GARF: 7523/45/371/2-3, 58-59).

18. Three officers sent a letter, arguing that the amount of alimony should be decided according to their regular salaries without including special allowance based on, say, remoteness (GARF: 7523/45/215/180-83). 
as the Principles of the legislation on marriage and family, which is most closely connected with the direct needs and desires of the broad range of people, if not every citizen without exception. This probably explains the exceptional liveliness, which all people showed at discussion of the draft.

(GARF: 7523/101/2586/91-92)

The deadlock in the legislative process was finally resolved by February 1968, after the Commissions of Legislative Proposals presented drafts to the Central Committee of the Party several times (GARF: 7523/101/2619/10-11). The final draft contained the most disputed condition, that is, establishing the paternity of children born out of wedlock. However, the conditions for establishing paternity were narrower than before. ${ }^{19}$ Furthermore, another disputed issue, the administrative divorce, was completely eliminated. ${ }^{20}$ The archival materials do not clearly show why and how this happened.

\section{All-People's Discussion}

All-people's discussions (vsenarodnoe obsuzhdenie) were often held after Stalin's period as a means of realizing the directness of Soviet democracy, but they were only a form of consultation, unlike a more direct referendum. Although the first all-people's discussion was conducted with the approval of the 1936 Stalin constitution on the grounds that the former ruling classes no longer existed, publication and public discussion of bills had been common before the constitution in the name of participation of the masses (Коток 1964, 74-80). Western scholars usually took this as an attempt to put a face of legitimacy on the process, understanding the discussions to be a mere formality (MORISHITA 1981; SCHNEIDER 1979; SHARLET 1977; FrIEDRICH and BRZEZINSKI 1965). However, that is not the case with the Principles argued here. The discussions were neither a disguise nor a mere formality. Nonetheless, as I comment in the conclusion, crucial problems existed within Soviet democracy.

After the draft was approved by the Central Committee, the Presidium of the Supreme Soviet resolved to publish the draft for an all-people's discussion (Vvs SssR, 1968, 16, 133). The final draft was published on April 9,

19. The wording was, as Izvestiia reported on April 9, 1968: "On the establishment of paternity, the court considers cohabitation and conducting common household by the mother of the child and the defendant till the birth of the child, or joint upbringing or the financial support to the child by them." See also notes 14 and 15 .

20. Simplification of the judicial divorce procedure was no longer the issue at this moment, because an edict on this matter had already been enacted in 1965 (Vvs SssR 1965, $49,725)$. 
1968, in Izvestiia and other media. ${ }^{21}$ People concerned about family law sent letters to express their opinions. For example, Izvestiia reported on April 21 that the paper had received about 8,00o letters, and the editorial team published several in the paper for discussion among readers. ${ }^{22}$ The Presidium of the Supreme Soviet received about 4,0oo letters from citizens (GARF: 7523/101/2544/36). ${ }^{23}$

During the discussion, the Presidium staff prepared two sets of materials from the letters (GARF: 9514/1/555/146-254, 255-78) and received materials from other organizations and republics. ${ }^{24}$ The drafting group of the subcommittee of the Commissions of Legislative Proposals met sixteen times from May 16 to June 5 to revise the draft to reflect letters from citizens, apparently using these materials (GARF: 7523/101/2619/76-307). There were two important revisions. First, the conditions for establishing the paternity of children born out of wedlock were broadened somewhat. Second, administrative divorce was introduced. The revised draft was approved by the subcommittee and then by the preparatory commission, which consisted of members of the drafting group, representatives of state and social organizations, and deputy members of the six standing commissions of the Chambers, including the Commissions of Legislative Proposals (GARF: 7523/101/2620/1; GARF: 7523/101/2621/1-90; GARF: 7523/101/2544/27-47). After the draft was discussed and reasons for rejecting proposals in a plenary session of the Supreme Soviet were explained, the Principles were enacted on July 27 (Zasedaniia Verkhovnogo Soveta SSSR 1968, 175-212, 222-24).

As far as letters in the papers and the archives show, people who sent letters freely wrote what they believed. This was partly because family law was not as politically critical as, say, the Party Program. However, there were letters with ideas unlikely to be justified by Soviet ideology. Some letter writers argued that there should be a head of the family. One was published by Izvestiia on May 6, 1968. Others were sent to the Supreme

21. In addition to Izvestiia, the draft was published in Literaturnaiia Gazeta on April 10, and in Sovet Deputatov Trudiashchikhsia (1968). Other media carried commentaries on the draft (Kuznetsov 1968; Sovetskaia Iustitsiia 1968; SAdikov 1968). A women's journal held a meeting on the draft (KonONENKo 1968).

22. Twelve discussions were held in the paper: April 24 and 26, May 6, 13, 17, 22, 24, and 29 , and June 5, 12, 14, and 19.

23. Letters were kept at GARF: 7523/101/2630-70.

24. Materials came from the Turkmen, Moldavian, Azerbaijan, Uzbek, and Lithuanian republics (GARF: 7523/101/2555/25; GARF: 7523/101/2623/1-104) as well as the editorial in Izvestiia (GARF: 7523/101/2619/204-43). 
Soviet, including a letter that even insisted family members had to follow the head of the family if he changed places of residence, although such norms were clearly out of favor after the revolution in the name of equality between men and women in the family (GARF: 7523/101/2661/21-22, 52-53, 54-55, 66). One letter sent after the Principles were approved argued that the all-people's discussion was useless because the law did not reflect letters people had sent and no persuasive reasons were offered for this failure to include them (GARF: 7523/101/2669/76, 77) ${ }^{25}$

Even if the discussion had been conducted freely, it would be meaningless if the conclusion was previously determined. In this regard, it is worth pointing out that members of the subcommittee actively participated in the discussion, rewriting the draft at the same time. Interestingly, only one member supported the published draft entirely (KuLIKov 1968); ${ }^{26}$ many others criticized it and demanded broadened conditions for establishing paternity and the introduction of administrative divorce (BRATUs', Fleishits, and Pergament 1968; Ershova 1968; Orlova 1968; TadevoSIAN 1968). ${ }^{27}$ It was natural that these people would criticize the published draft, since they had wished to ease the conditions of paternity as much as possible (Orlova 1962; Pergament 1956). ${ }^{28}$

The archival materials show no indication of a decision made in advance. Those who criticized the published draft made considerable effort to expand the chances for establishing paternity as well as introducing an administrative divorce procedure during the revision of the draft, relying on letters demanding those revisions (GARF: 7523/101/2619/108-11; GARF: 7523/101/2621/45-46). It is noteworthy that administrative divorce was approved for incorporation in the draft because many people wanted it, while the majority of the drafting group did not support it at first (GARF: 7523/101/2619/101-2). The confrontation between the two sides continued at the meeting of the preparatory commission. N. M. Ershova, a member of the drafting group who favored introducing administrative

25. This man sent the same letters to the Presidium of the Supreme Soviet and the Central Committee of the Party, putting his name and address in the letters.

26. He was the first vice president of the Supreme Court of the UssR and headed the subcommittee.

27. Among them, Bratus' and Fleishits participated in the legislative process only under Stalin's government.

28. Orlova and Pergament had both been members of the subcommittee from 1961 until the end of the process. 
divorce, tried to persuade her colleagues and thereby convince deputies and other representatives, saying:

We started with numerous wishes of the citizens. The vast majority of proposals state that there is no need to block up judicial bodies with affairs about divorces in those cases, when there is no dispute [but] there is an agreement, and especially in the cases when the decisions of the court are made in relations with persons [recognized as] insane and prisoners sentenced [to deprivation of liberty] for more than three years.

(GARF: 7523/101/2621/49)

Citizens' letters led to changes in the disputed articles of the draft; in this case at least, the all-people's discussion functioned as officially expected. It is possible that the published draft was written so that it contained only provisions that would not cause objections from the Party and in a way that those who determined the final, published draft expected would allow modification through the all-people's discussion.

\section{Conclusion}

Self-government was of course a fiction in the Soviet Union, as in any modern state. However, participation through sending letters and attending discussions gave self-government a certain reality and helped to legitimize the Soviet regime. Therefore, listening to the people was an important obligation for the authorities. After Stalin, the government encouraged people to send letters to the authorities and actively used the all-people's discussions. The loosened demand for unanimity made it possible for people to express themselves more casually and share their opinions. Although the case examined here shows a limited picture, the letter writers believed that they were entitled to demand policy changes, and the draft writers, including specialists, officials, and deputies, felt obliged to respond to those demands. Regarding the process of creating the Principles, direct participation worked largely as expected in the ideology of Soviet democracy, although it took many years.

However, there were some problems in this process. First, the government and the Party did not always agree to the proposals that citizens sent, even when numerous people demanded the same thing. Certain categories of demands were not acceptable for ideological reasons, such as a ban or further restrictions on divorce. Furthermore, demands could be arbitrarily selected. In settling disputes, the government often picked easy cases and solved them for propaganda purposes (KoROLEV 1995, 
40-41). ${ }^{29}$ This arbitrariness might have undermined belief in the legitimacy of the regime.

Second, ideology did not necessarily establish priority for the demands received. For instance, under the policy of strengthening of the family, ideological considerations could not fix exclusive conditions for establishing the paternity of children born out of wedlock. Some tried to narrow the conditions to preserve existing families, while others demanded the easing of conditions to save children who were not responsible for their legal status. It was difficult to predict the consequences in advance.

Third, vexing problems existed in the all-people's discussions. The Supreme Soviet was not obliged to agree with all proposals from citizens, only to consider them, when it amended the original draft of a law. Kotok, a specialist on this theme, argued that the all-people's discussions were a better form of participation than a referendum; while the latter only let people express a yes or no opinion, the former allowed them to make more precise demands and proposals (Коток 1964, 177). However, how to determine what should be adopted was unclear. Kotok stated only that the Commissions of Legislative Proposals should "select rational proposals" and did not explain how the deputies of those commissions could appropriately determine which proposals were "rational" (Коток 1964, 176). The vagueness of his argument was seemingly caused by the need for the unanimity of interests, which prevented him from thoroughly dealing with contradictions between various demands. Furthermore, the directness of participation could be undermined, since it was the Supreme Soviet, not the people, that made the final decisions.

Fourth, the role of specialists and officials was problematic. Specialists and officials had to make clear choices based solely on their specialized knowledge without accommodating other opinions. However, they in essence created the drafts to change the existing law. No citizen proposals were incorporated in the drafts unless they decided so. They even did not hesitate to advocate opinions that the Party did not agree with. This was clearly shown in the case of determining the conditions for establishing paternity. Moreover, the specialists selected letters from citizens based on their own preference and used them to convince deputies, although the specialists themselves had less legitimacy than the deputies, the people, and the Party. Objectively, specialists gave higher priority to their special-

29. Korolev was an official who had worked at the Presidium of the Supreme Soviet for a long time since Stalin headed the government and had participated in drafting the Principles. 
ized knowledge and their own proposals than to the opinions of deputies and even citizens.

Finally, the role the Party and its leaders played in the entire process should be questioned. There were no signs that they determined controversial issues, as archival materials I have mentioned in this article suggested. They refused drafts several times, mainly because of the article on establishing the paternity of children born out of wedlock, but they did not provide the final answer. According to the idea of Soviet democracy, the Party, as the vanguard, was obliged to determine what was suitable for socialism and communism. The Party had to reconcile and harmonize interests to attain final unanimity and thus solve problems. If the Party could not function as expected, the policy-making process would easily become deadlocked. This was especially the case when the need for unanimity was relaxed.

Without the unanimity of interests and the Party as champion of this unanimity, as well as the people's belief in both, it was difficult for Soviet democracy to function properly. The requirements for realizing Soviet democracy seem far more difficult to fulfill than those in liberal democracies, where politics means reconciliation and negotiation among different interests, in rare cases bringing about zero-sum results. The Soviet regime was undermined not only because of its repressiveness, but also because of its unique ideas of democracy. 


\section{References}

Alexopoulos, Golfo

2003 Stalin's Outcasts: Aliens, Citizens, and the Soviet State, 1926-1936. Ithaca, NY: Cornell University Press.

Andreev, E. M., L. E. Darskit, and T. L. Khar'kova

1993 Naseleniia Sovetskogo Soiuza. 1922-1991. Moscow: Nauka.

Aтtwood, Lynne

2010 Gender and Housing in the Soviet Russia: Private Life in a Public Space. Manchester: Manchester University Press.

Beliakova, A. M.

1970 "Roshia kyōwakoku shin kazoku hō ni tsuite" (On the new Russian Family Law). Foreword and translation by Isamu Fujita and Seizou Tadakawa. Hōritsu jihō 42 (7): 158-65.

BitTner, Stephen V.

2008 "Local Soviets, Public Order, and Welfare after Stalin." The Russian Review 62 (2): 281-93.

Bratus', C., E. Fleishits, and A. Pergament

1968 "Dolg otsa." Izvestiia, May 6.

BURLATSKII, F. M.

1962 "O nekotorykh voprosakh teorii obshchenarodnogo sotsialisticheskogo gosudarstva." Sovetskoe gosudarstvo i pravo 10: 3-14.

CARLBÄck, Helene

2009 “Lone Mothers and Fatherless Children.” In Soviet State and Society under Nikita Khrushchev, Melanie Ilic and Jeremy Smith, eds., 86-103. London and New York: Routledge.

Crick, Bernard

2005 In Defence of Politics. 5th ed. London and New York: Continuum.

DAHL, Robert A.

1971 Polyarchy: Participation and Opposition. New Haven and London: Yale University Press.

Ershova, N.

1968 "V interesakh detei." Izvestiia, May 24.

FitzPATRICK, Sheila

1996 "Supplicants and Citizens: Public Letter-Writing in Soviet Russia in the 1930s." Slavic Review 55 (1): 78-105.

Friedgut, Theodore $\mathrm{H}$.

1979 Political Participation in the USSR. Princeton, NJ: Princeton University Press. 
Friedrich, Carl J., and Zbigniew K. BRZEZINSKI

1965 Totalitarian Dictatorship and Autocracy. 2nd ed. Cambridge, MA: Harvard University Press.

GAK, G. M.

1955 "Obshchestvennye i lichnye interesy i ikh sochetanie pri sotsialisme." Voprosy filisofii 4: 17-28.

GARF (State Archive of Russian Federation; numbers in the text show fond, opis, delo and listy, respectively).

Geiger, H. Kent

1968 The Family in Soviet Russia. Cambridge, MA: Harvard University Press.

Goldman, Wendy Z.

1993 Women, the State and the Revolution: Soviet Family Policy and Social Life, 1917-1936. Cambridge and New York: Cambridge University Press.

Hasebe, Yasuo

2006 "Reisen no shūketsu to kenpō no hendō" (The end of the Cold War and the conversion of the Constitution). In Kenpō no risei (Reason of Constitution), 46-59. Tokyo: University of Tokyo Press.

HeLd, David

2006 Models of Democracy. 3rd ed. Cambridge and Malden, England: Polity Press.

HornsBy, Robert

2011 "The Outer Reaches of Liberalization: Combating Political Dissent in the Khrushchev Era." In Khrushchev in the Kremlin: Policy and Government in the Soviet Union, 1953-1964, by Jeremy Smith and Melanie Ilic, eds., 61-78. London and New York: Routledge.

Juviler, Peter H.

1967 "Family Reform on the Road to Communism." In Soviet Policy-Making: Studies of Communism in Transition, Peter H. Juviler and Henry Morton, eds., 29-6o. London: Praeger.

KawAмото, Kazuko

2012 Soren no minshushugi to kazoku: Renpou kazoku kihonhou seitei katei 1948-1968 (Soviet democracy and the family: Family Law reform after the war, 1948-1968). Tokyo: Yushindo.

2002 "Sovet taisei no kihonkouzou haaku no kokoromi" (In search of the fundamental structure of the Soviet regime). Roshia-shi Kenkyu 71: 27-44.

1998 "Khrushchev ki no Soren ni okeru seisaku keisei: Kazokuhou kaisei wo meguru giron wo chūshin ni" (Policy making in the Khrushchev era: From the discussion on Family Law reform). Kokkagakkai Zasshi 111 (1-2): $109-76$. 


\section{Kommunisticheskaia Partiia}

1986 Sovetskogo Soiuza v rezoliutsiiakh $i$ resheniiakh s"ezdov, konferentsii $i$ plenumov TsK, tom. 9. Moscow: Izdatel'stvo politicheskoi literatury.

Kononenko, E.

1968 "Kulb obshchestvennits, vtoroe zasedanie: Obsuzhdaem proekt Osnov zakonodatel'stva o brake i sem'e." Rabotnitsa 5: 22-23.

Korolev, Iu. A.

1995 Kremlevskii sovetnik. Moscow: Olimp.

Коток, V. F.

1964 Referendum $v$ sisteme sotsialisticheskoi demokratii. Moscow: Izdatel'stvo Nauka.

Kulikov, V.

1968 "Stoit li vozvrashchatsia." Izvestiia, May 17.

Kuznetsov, S. V.

1968 "Brak, sem'ia i zakon." Ogonek 24: 6-7.

LENIN, V. I.

1977 "Gosudarstvo i revoliutsiia." Polnoe sobranie sochinenii, 5-oe izd., tom. 33, 1-120. Moscow: Izdatel'stvo politicheskoi literatury.

LEPESHKIN, A. I.

1962 "Obshchenarodnoe gosudarstvo i ego osnovnye cherty." Sovetskoe gosudarstvo i pravo 9: 3-15.

Macpherson, Crawford B.

1972 The Real World of Democracy. New York: Oxford University Press.

Matsudo, Kiyohiro.

2008 "1960 nendai no Soren ni okeru chihougyousei no ichisokumen" (One aspect of Soviet local government in the 1960s). Hokkaigakuen Daigaku Hougaku Kenkyu 44 (2): 191-231.

Morishita, Toshio

1981 "Shoki Sobieto ni okeru kazokuhou riron no tenkai (1)" (Development of theories of Soviet Family Law in the early Soviet period). Kobe Hougaku Zasshi 30 (4): 849-921.

NAKACHI, Mie

2006 "N. S. Khrushchev and the 1944 Family Law: Politics, Reproduction and Language." East European Politics \& Societies 20 (1): 40-68.

Oliver, James

1969 "Citizen Demands and the Soviet Political System." American Political Science Review 63 (2): 465-75.

Orlova, N.

1968 “Ne Tol'ko lichnoe." Izvestiia, May 29.

1962 “K Razrabotke zakonodatel'stva o brake i sem'e." Sovetskaia iustitsiia 7: 7-9. 
Pergament, A. I.

1956 "Pravovoe polozhenie vnebrachnykh detei dolzhno byt' izmeneno." Sovetskoe gosudarstvo i pravo 9: 65-72.

Poliakov, S. A., and V. B. Zhiromskaia, eds.

2001 Naselenie Rossii v XX veke: Istoricheskie ocherki. tom. 2. 1940-1959. Moscow: Rosspen.

Priestland, David.

2002 “Soviet Democracy, 1917-91." European History Quarterly 32 (1): 111-30.

SADIKOV, O.

1968 “Proekt novogo Osnovnogo zakona o brake i sem'e." Agitator 11: 18-20.

SCHNEIDER, Eberhard.

1979 "The Discussion of the New All-Union Constitution in the USSR." Soviet Studies 31 (4): 523-41.

SHARLET, Robert.

1977 “The New Soviet Constitution.” Problems of Communism 26 (5): 1-24.

Sovet Deputatov Trudiashchikhsia

1968 "Proekt. Osnovy zakonodatel'stva Soiuza SSR i soiuznykh respublik o brake i sem'e." May: 14-22.

Sovetskaia iustitsiia

1968 "K opublikovaniiu proekta Osnov zakonodatel'stva Soiuza SSR i soiuznykh respublik o brake i sem'e." 9: 18-20.

STALIN, I. V.

1997a "O proekte Konstitutsii Soiuza SSR: doklad na chrezvychainom VIII Vsesoiuznom S” ezde Sovetov 25 noiabria 1936 goda.” Sochineniia, tom. 14, 119-47. Moscow: Izdatel'stvo pisatel'.

1997b "O nedostatkakh partiinoi raboty i merakh likvidatsii Trotskistskikh i inykh dvurushnikov. Doklad na plenume TsK VKP(b) 3 marta 1937 g." Sochineniia, t. 14, 151-73. Moscow: Izdatel'stvo pisatel'.

1951 "Itogi pervoi piatiletki. Doklad na ob" edinennom plenume TsK i TsIK(b) 7 ianvaria 1933 g." Sochineniia, tom. 13, 161-215. Moscow: Gosudarstvennoe izdatel'stvo politicheskoi literatury.

Stepanian, Ts. A.

1955 "Protivorechiia v razvitii sotsialisticheskogo obshchestva i puti ikh preodoleniia." Voprosy filisofii 2: 69-86.

Su RsfsR (Collection of Laws and Regulations of the Workers' and Peasants' Government of the RSFSR; numbers in the text show year, issue and item, respectively.)

SverdLov, G.

1941 "O predmete i sisteme sotsialisticheskogo semeinogo prava." Sovetskoe gosudarstvo i prava 1:57-69. 
Sz SssR (Collection of Laws and Regulations of the Workers' and Peasants' Government of the UsSR; numbers in the text show year, issue and item, respectively.)

TADEvosian, V.

1968 “Razumno i spravedlivo." Izvestiia, May 6.

TALMON, Jacob Leib

1952 The Origins of Totalitarian Democracy. London: Secker \& Warburg.

Tiтov, Alexander.

2009 “The 1961 Party Programme and the Fate of Khrushchev's Reforms.” In Soviet State and Society under Khrushchev: Policy and Government in the Soviet Union, 1953-1964, Jeremy Smith and Melanie Ilic, eds., 8-25. London and New York: Routledge.

Vvs SssR (Gazette of the Supreme Soviet of the UssR; numbers in the text show year, issue and item, respectively.)

Zasedaniia Verkhovnogo Soveta SssR (tret'ia ssesiia)

1947 Stenograficheskii otchet, 20-25 fevralia. Moscow: Izdanie Verkhovnogo Soveta SSSR.

Zasedaniia Verkhovnogo Soveta SSSR sed'mogo sozyva

1968 Chetvertaia sessia, 25-27 iunia, stenogaficheskii otchet. Moscow: Izdanie Verkhovnogo Soveta SSSR.

Zuвкоva, Elena Iurievna

2000 Poslevoennoe sovetskoe obshchestvo: Politika i povsednevnost,' 1945-1953. Moscow: Rosspen. 